Provided for non-commercial research and education use. Not for reproduction, distribution or commercial use.

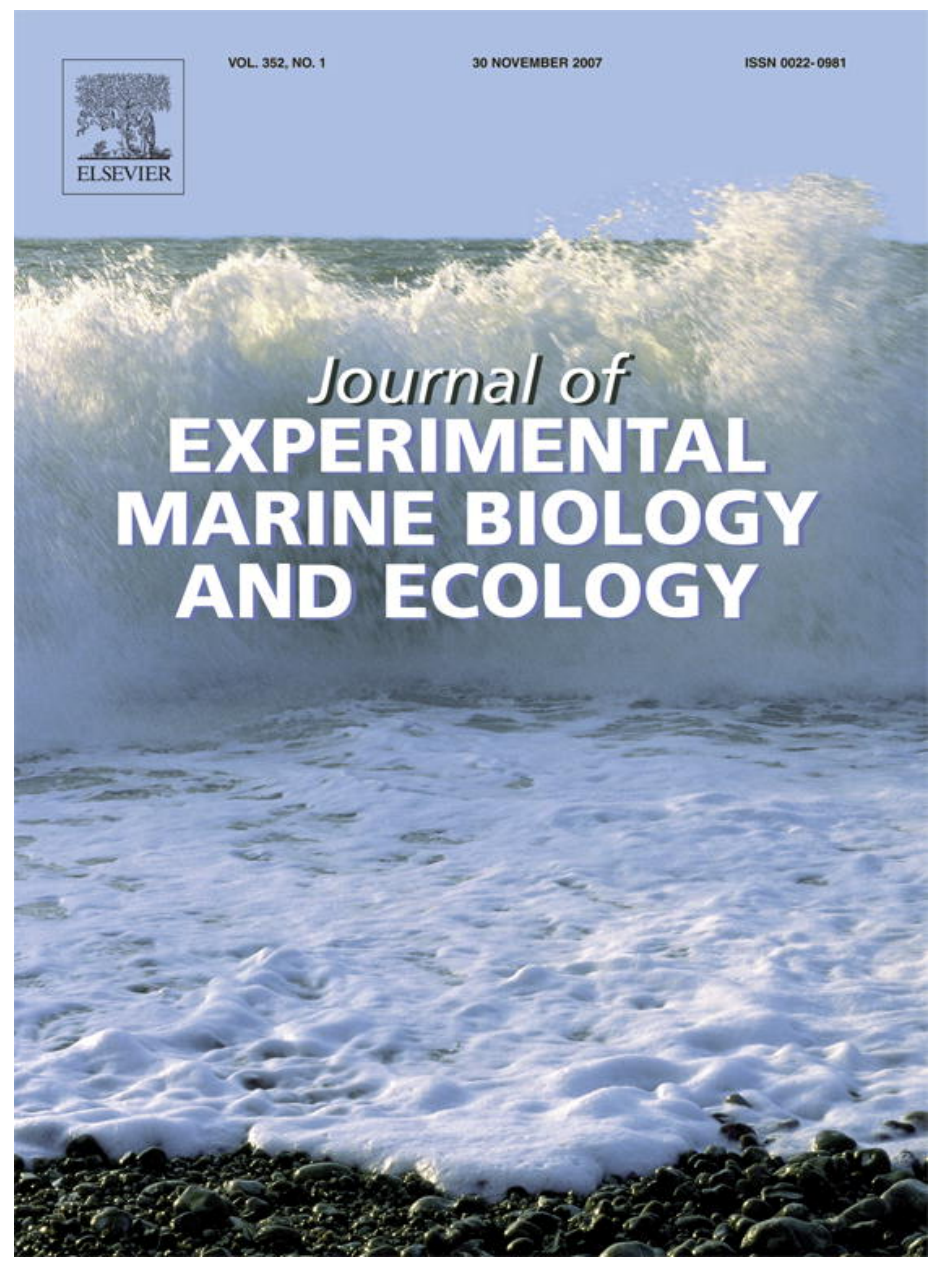

This article was published in an Elsevier journal. The attached copy

is furnished to the author for non-commercial research and education use, including for instruction at the author's institution, sharing with colleagues and providing to institution administration.

Other uses, including reproduction and distribution, or selling or licensing copies, or posting to personal, institutional or third party websites are prohibited.

In most cases authors are permitted to post their version of the article (e.g. in Word or Tex form) to their personal website or institutional repository. Authors requiring further information regarding Elsevier's archiving and manuscript policies are encouraged to visit: 


\title{
Larval development of the subantarctic squat lobster Munida subrugosa (White, 1847) (Anomura: Galatheidae), reared in the laboratory
}

\author{
Patricia Pérez-Barros ${ }^{a, *}$, Sven Thatje ${ }^{\mathrm{b}}$, Javier A. Calcagno ${ }^{\mathrm{c}}$, Gustavo A. Lovrich ${ }^{\mathrm{a}}$ \\ a Centro Austral de Investigaciones Cientificas, Consejo Nacional de Investigaciones Científicas y Técnicas (CADIC - CONICET), \\ CADIC - CC 92, V9410BFD Ushuaia, Tierra del Fuego, Argentina \\ ${ }^{\mathrm{b}}$ National Oceanography Centre, Southampton, School of Ocean and Earth Science, University of Southampton, SO14 3ZH Southampton, UK \\ ${ }^{\mathrm{c}}$ Facultad de Ciencias Exactas y Naturales, Universidad de Buenos Aires, CONICET, Pabellón II Ciudad Universitaria, \\ C1428EHA - Buenos Aires, Argentina
}

Received 20 April 2007; received in revised form 25 June 2007; accepted 29 June 2007

\begin{abstract}
The larval development of the squat lobster Munida subrugosa from subantarctic waters of the Beagle Channel (Tierra del Fuego, Argentina) was studied under controlled laboratory conditions of temperature, salinity, and food supply. Developmental times, survival, and growth of larvae and early juveniles were investigated. Hatching of the entire brood always occurred during one night. Larvae were kept in $100 \mathrm{ml}$ individual bowls with filtered seawater at $8 \pm 0.5^{\circ} \mathrm{C}$ and fed with Artemia spp. nauplii three times a week. Larvae passed through 6 zoeal instars and one megalopa. Previously, only five zoeal instars were known from this species. Mean cumulative durations of the zoeal stages I to VI were: $20.5 \pm 2.5,33.9 \pm 4.1,43.3 \pm 5.4,52.6 \pm 5,61.2 \pm 3.9$, and 83 days, respectively. By adding the 28 days that a single megalopa took to metamorphose to crab I stage, the complete larval development lasted 111days. Highest mortality occurred prior to the moult from the zoea I to zoea II stage $(79.21 \% \pm 18.65 \%)$ and during the moult from zoea VI to megalopa (92.86\%). Carapace length was $1.64 \pm 0.06,1.52 \pm 0.16,1.57 \pm 0.26,1.64 \pm 0.21,2.11 \pm 0.35$, and $2.58 \pm 0.19 \mathrm{~mm}$, for zoeal stages I to VI, respectively. Carapace length of megalopae and crab I instars was similar (2.85 \pm 0.28 and the $2.84 \pm 0.05$, respectively). Unlike other subantarctic decapods, which show a tendency towards abbreviated larval development and/or some degree of endotrophy, M. subrugosa shows an extended planktotrophic larval development synchronized with short seasonal plankton production in austral summers.
\end{abstract}

(C) 2007 Elsevier B.V. All rights reserved.

Keywords: Beagle Channel; Decapods; Growth; Larvae; Survival

\section{Introduction}

Munida subrugosa is a very abundant galatheid crab in waters off South America and New Zealand, and cooccurs with Munida gregaria (Fabricius, 1793) along all

\footnotetext{
* Corresponding author. Tel.: +54 2901 422310, fax: +54 2901 430644.

E-mail address: patopb@yahoo.com (P. Pérez-Barros).
}

its distribution (Chilton, 1909; Matthews, 1932; Rayner, 1935). In South America, M. subrugosa and M. gregaria occur in Atlantic waters on the continental shelf from Uruguay $\left(35^{\circ} \mathrm{S}\right)$ to Cape Horn $\left(55^{\circ} \mathrm{S}\right)$, including the Islas Malvinas/Falkland Islands, whereas on the Pacific side they occur up to the island of Chiloé $\left(41^{\circ} \mathrm{S}\right.$, Chile) (Tapella et al., 2002b). The Beagle Channel constitutes one of the southernmost sites in the distribution of these species (c.f. Gutt et al., 1999). 
The great abundance of $M$. subrugosa has been reported since the beginning of the 20th century (Matthews, 1932; Rayner, 1935). In the Beagle Channel, density of adults can be as high as 27 individuals $\cdot \mathrm{m}^{-2}$ (Gutt et al., 1999), or average $6780 \pm 11,010$ individuals $\cdot 10,000 \mathrm{~m}^{-2}$ (PérezBarros et al., 2004). In the Atlantic continental shelf, 14,000t of Munida spp. were calculated as the annual bycatch of the fishery for the shrimp Pleoticus muelleri (Villarino et al., 2002).

Great confusion about the relation between these two species has plagued the literature since the end of the 19th century (Matthews, 1932). Since then, some authors suggest that $M$. gregaria and $M$. subrugosa are two different species, whereas others support the view that $M$. gregaria is the juvenile form of $M$. subrugosa (Matthews, 1932). Notwithstandingly, most authors agree that the postlarval form of $M$. gregaria is planktonic, while the postlarvae of $M$. subrugosa live at the benthic surface (Matthews, 1932). Summer pelagic shoals of postlarvae or early juveniles of Munida have already been reported by the end of the 16th century from Patagonian waters (Matthews, 1932). However, at present they appear to be much more common in New Zealand waters (Williams, 1973; Jillett and Zeldis, 1985) than in southern South America. In the Beagle Channel, the occurrence of pelagic shoals of Munida spp. is only occasionally reported by local fishermen. Adults of both species are exclusively benthic, and young as well as adults are captured in benthic samples (Tapella et al., 2002b).

Larval hatching of Anomura in the Beagle Channel is clearly seasonal (Lovrich, 1999). Munida spp. larvae have an extended planktonic development (Roberts, 1973; Thatje et al., 2003). Zoeae I of Munida spp. occur in the plankton between August and March, suggesting the existence of two cohorts per year, a spring and a summer one (Lovrich, 1999). Larvae of Munida spp. from the Southern Ocean have been described from plankton samples by Rayner (1935) and Roberts (1973). Rayner (1935) described larvae of Munida from the Islas Malvinas/Falkland Islands, and Roberts (1973) described the larvae of Munida subrugosa found in Perseverance Harbour plankton samples (Campbell Island, New Zealand).

Thorson's old ecological concept (Thorson, 1936; 1950), argues that the mismatch between a marked seasonality of primary production (i.e. food availability) and prolonged larval developmental times due to low temperatures at high latitudes, should strongly select against extended planktotrophic larval development (Thatje et al., 2003). Tendencies to develop endotrophy and abbreviated larval cycles in decapods at high latitudes have been frequently suggested as mechanisms that would enable certain species to thrive under polar conditions (Lovrich and Thatje, 2006). However, some subantarctic decapods, i.e. Pagurus comptus, do not follow this tendency, and show an extended and fully planktotrophic larval development in high latitudes (Lovrich and Thatje, 2006).

In this study we present for the first time information on the developmental times, survival, and growth of larvae of M. subrugosa reared under controlled laboratory conditions. We compare and discuss the early life history pattern of $M$. subrugosa with that of other decapod species that have adapted to the environmental conditions of short periods in food availability (short summers) and low water temperatures prevailing in the subantarctic (Thatje et al., 2003).

\section{Materials and methods}

\subsection{Sampling and maintenance of organisms}

Ovigerous females of $M$. subrugosa were caught in the Beagle Channel $\left(54^{\circ} 53.8^{\prime} \mathrm{S}, 68^{\circ} 17.0^{\prime} \mathrm{W}\right)$ in December 2004, using an epibenthic trawl of $10 \mathrm{~mm}$ mesh size. Specimens were maintained individually in 1-litre aquaria at a constant temperature of $8 \pm 0.5^{\circ} \mathrm{C}$, and an artificial 12:12h light:dark cycle. Water was changed and females were fed TetraFin Goldfish flakes three times a week.

\subsection{Rearing of larvae}

Larvae hatched during the night were randomly collected from the aquaria using a long glass pipette the following morning. Larvae were kept individually in bowls containing $100 \mathrm{ml}$ filtered seawater and at $8 \pm$ $0.5^{\circ} \mathrm{C}$. Larvae were checked daily for exuviae or mortality. Water was changed three times a week. Freshly hatched Artemia nauplii (Sanders Brine Shrimp Company, USA) were supplied as food ad libitum after water changes. Larvae used in this study hatched from 4 different females. The initial number of larvae cultured per female was: Female $A=48$, Female $B=72$, Female $\mathrm{C}=96$ and Female $\mathrm{D}=78$. On reaching the megalopa stage, each bowl received a piece of nylon mesh as an artificial substrate facilitating settlement and metamorphosis of the megalopa.

Larvae of each stage were sampled alive and fixed in $4 \%$ buffered formalin seawater. Larval carapace (CL) and total (TL) lengths were measured, from the tip of the rostrum to the mid-dorsal posterior margin of the carapace, and to the cleft of the tail fan, respectively. Measurements were made with a binocular microscope 
Table 1

Average lengths (TL: total length and CL: carapace length) and cumulative developmental times of Munida subrugosa from the Beagle Channel, southernmost South America

\begin{tabular}{|c|c|c|c|c|c|}
\hline & \multirow[t]{2}{*}{$\mathrm{TL}(\mathrm{mm})$} & \multirow[t]{2}{*}{$\mathrm{CL}(\mathrm{mm})$} & \multicolumn{3}{|c|}{ Cumulative developmental time (days) } \\
\hline & & & $\mathrm{B}$ & $\mathrm{C}$ & $\mathrm{D}$ \\
\hline Zoea I & $2.9(0.12 ; 17)$ & $1.64(0.06 ; 18)$ & & & \\
\hline Zoea II & $3.05(0.27 ; 12)$ & $1.52(0.16 ; 12)$ & $20(5.6 ; 6)$ & $20.5(2.5 ; 34)$ & $20.6(4.4 ; 11)$ \\
\hline Zoea III & $3.25(0.55 ; 6)$ & $1.57(0.26 ; 6)$ & $35.3(3.8 ; 4)$ & $33.9(4.1 ; 25)$ & $31.5(2.1 ; 4)$ \\
\hline Zoea IV & $3.57(0.53 ; 6)$ & $1.64(0.21 ; 5)$ & $47(0 ; 1)$ & $43.3(5.4 ; 15)$ & $44(1 ; 3)$ \\
\hline Zoea V & $4.26(0.52 ; 7)$ & $2.11(0.35 ; 7)$ & $58(0 ; 1)$ & $52.6(5 ; 10)$ & $59(2.8 ; 2)$ \\
\hline Zoea VI & $5.38(0.71 ; 5)$ & $2.58(0.19 ; 5)$ & $74(0 ; 1)$ & $61.2(3.9 ; 6)$ & - \\
\hline Megalopa & $5.89(0.40 ; 9)$ & $2.85(0.28 ; 9)$ & - & $83(0 ; 1)$ & - \\
\hline Crab I & - & $2.84(0.05 ; 2)$ & - & $111(0 ; 1)$ & - \\
\hline
\end{tabular}

In brackets: standard deviation; and sample size for three different females: B, C, and D.

with the aid of an eyepiece micrometer to the nearest $0.025 \mathrm{~mm}$.

\section{Results}

\subsection{Larval developmental time}

The entire egg clutch of each female hatched during one night. The complete larval development comprised 6 zoeal stages and a megalopa. Mean cumulative durations of the zoeal stages I to VI were: $20.5 \pm 2.5$, $33.9 \pm 4.1,43.3 \pm 5.4,52.6 \pm 5,61.2 \pm 3.9$, and 83days, respectively (Table 1). By adding the 28days that a single megalopa took to metamorphose to crab I stage, the complete larval development, passing through 6 zoeal stages and a megalopa, lasted 111days.

\subsection{Larval survival}

Survival of successive larval stages varied greatly among hatches from different females (Table 2). In the case of female A, half of the larvae died 7days after hatching, and no larvae survived the ZI stage; the last one having died after 38days (Fig. 1A). Larvae hatched from female $\mathrm{C}$ were the only ones to reach the megalopa and crab I stages. In general, highest "within stage" mortality was found during the moult from zoea I to zoea II $(79.2 \% \pm 18.7 \%)$ and from zoea VI to megalopa (92.86\%).

\subsection{Larval growth}

At hatching, zoeae I were $2.90 \pm 0.12 \mathrm{~mm}$ TL (Table 1, Fig. 2). CL of megalopa and crab I instars were almost the same (2.85 \pm 0.28 and $2.84 \pm 0.05$, respectively). TL showed increments of: $5.1 \%$ from ZI to ZII, $6.5 \%$ from ZII to ZIII, 9.9\% from ZIII to ZIV, 19.2\% from ZIV to ZV, and $26.4 \%$ from ZV to ZVI. (Fig. 2).

\section{Discussion}

In this study we described the duration, survival rates, and sizes of larvae of the squat lobster M. subrugosa from the Beagle Channel. M. subrugosa showed an extended planktotrophic larval development synchronized with short seasonal plankton production in austral summers.

Table 2

Munida subrugosa: rates of survival of individual developmental stages ( $\%$ of survivors to a given stage) and cumulative survival from hatching to a given stage (as \% of initial number at hatching [cum. \%])

\begin{tabular}{|c|c|c|c|c|c|c|c|c|c|}
\hline \multirow[t]{2}{*}{ Female } & \multicolumn{2}{|l|}{ A } & \multicolumn{2}{|l|}{$\mathrm{B}$} & \multicolumn{2}{|l|}{$\mathrm{C}$} & \multicolumn{2}{|l|}{$\mathrm{D}$} & \multirow{2}{*}{$\begin{array}{l}\text { Average } \\
\pm \text { SD } \\
\text { Cum.\% }\end{array}$} \\
\hline & $\%$ & Cum.\% & $\%$ & Cum.\% & $\%$ & Cum.\% & $\%$ & Cum.\% & \\
\hline Zoea I & 0 & 0 & 15.28 & 15.28 & 44.79 & 44.79 & 23.08 & 23.08 & $20.79 \pm 18.65$ \\
\hline Zoea II & & & 72.73 & 11.11 & 65.12 & 29.17 & 38.89 & 8.97 & $16.42 \pm 11.09$ \\
\hline Zoea III & & & 62.50 & 6.94 & 78.57 & 22.92 & 71.43 & 6.41 & $12.09 \pm 9.38$ \\
\hline Zoea IV & & & 100.00 & 6.94 & 95.45 & 21.88 & 100.00 & 6.41 & $11.74 \pm 8.78$ \\
\hline Zoea V & & & 100.00 & 6.94 & 85.71 & 18.75 & 80.00 & 5.13 & $10.27 \pm 7.40$ \\
\hline Zoea VI & & & 80.00 & 5.56 & 77.78 & 14.58 & 0 & 0 & $6.71 \pm 7.36$ \\
\hline
\end{tabular}



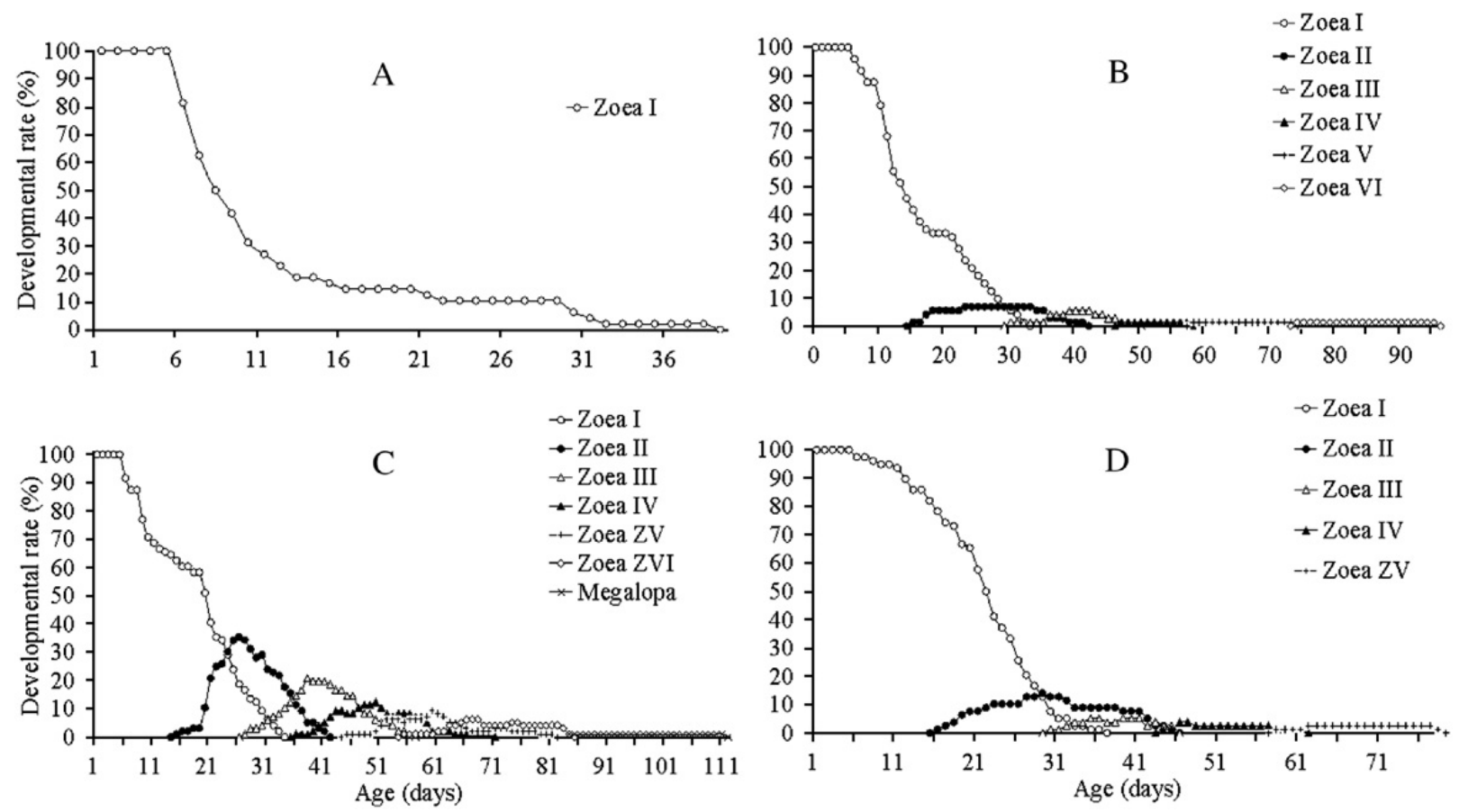

Fig. 1. Survival rates of Munida subrugosa larvae from 4 different females (A-D).

Our laboratory cultures revealed the existence of a 6th zoeal stage not present in previous descriptions from plankton samples, either from Islas Malvinas/Falkland Islands (Rayner, 1935) or New Zealand (Roberts, 1973). Plankton studies carried out in the Beagle Channel by Lovrich (1999) and Thatje et al. (2003) did only reveal 5 and 4 zoeal morphotypes of $M$. subrugosa, respectively. There are several possible explanations for the occurrence of a 6th zoeal stage not previously recorded. On the one hand, it is difficult to determine the number of zoeal stages present in plankton samples if the larval instars are very similar in size and morphology, and/or the developmental cycle is not well known. Rayner (1935) assumed that the 5th may not be the last zoeal stage of the Munida spp. he described. However, by comparison with the last stage of Munida banffica he defined the zoea $V$ as such. Furthermore, it is not certain that Lovrich (1999) did not find the 6th zoeal stage in the Beagle Channel, since he relied on the descriptions made by Roberts (1973).

The additional zoeal stage found in this study can also be attributed to the fact that larval developments of decapod crustaceans can be highly variable in the number of larval stages and developmental pathways; a pattern

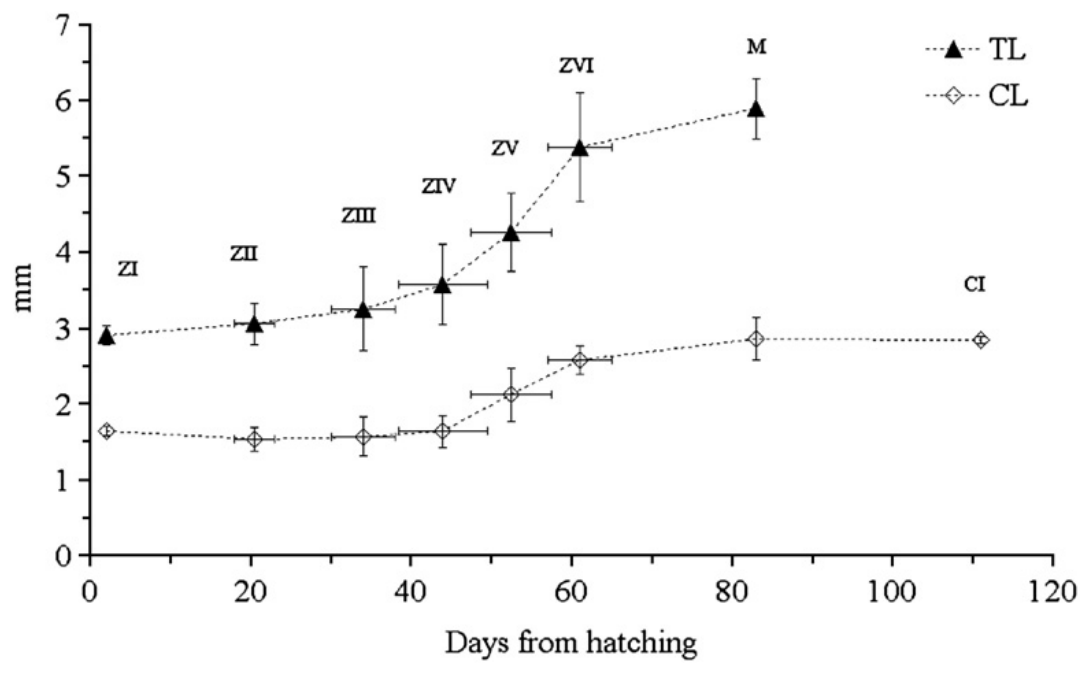

Fig. 2. Munida subrugosa larval total (TL) and carapace lengths (CL). ZI-ZVI: zoea I to VI, M: megalopa and CI: crab I. Days from hatching correspond to the average time from birth date. 

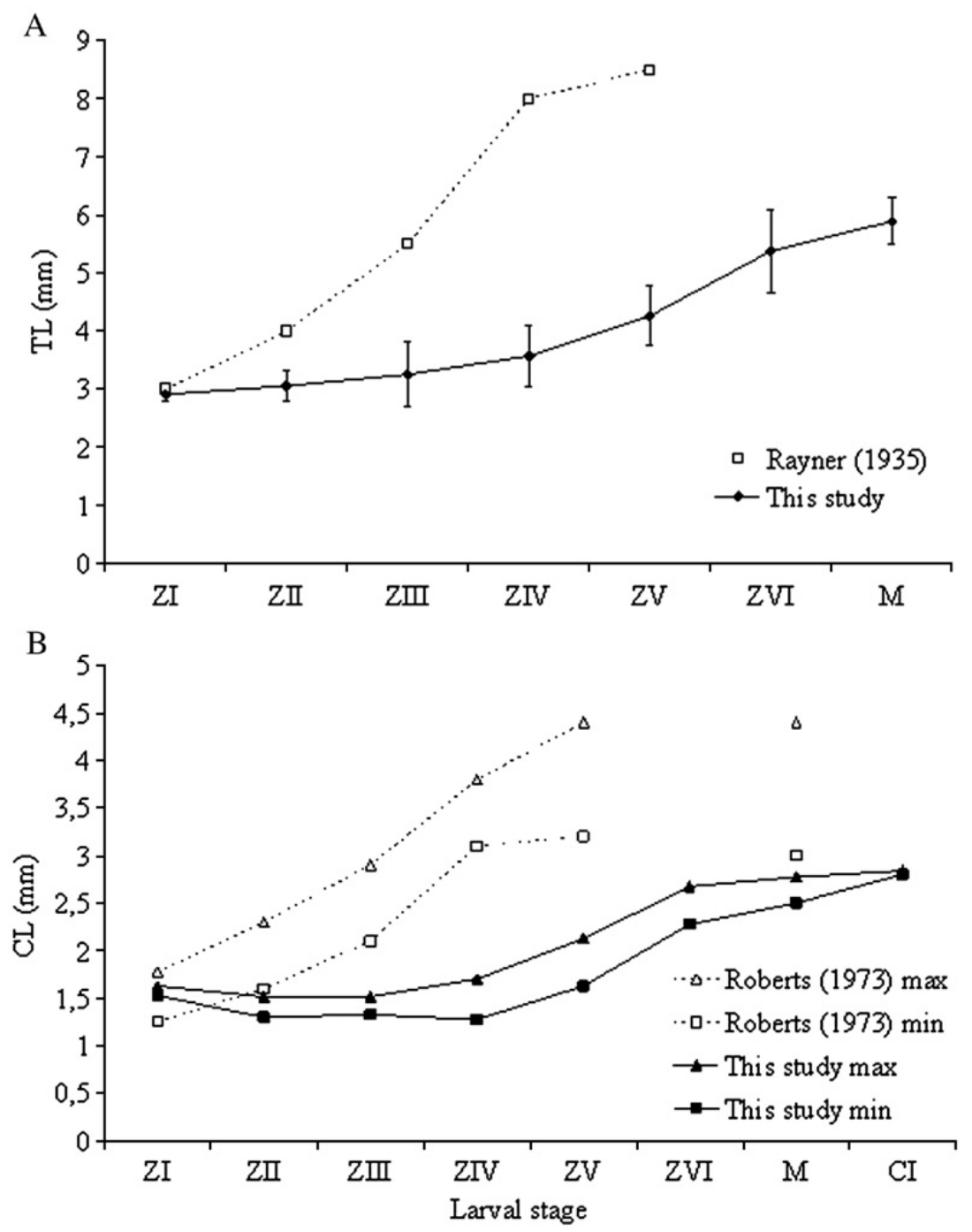

Fig. 3. (A) Average total lengths (TL) of M. subrugosa larvae obtained in the laboratory and Munida spp. larvae from plankton samples from Islas Malvinas/Falkland Islands (Rayner, 1935). (B) Maximum and minimum carapace lengths (CL) of M. subrugosa larvae from this study, and from plankton samples off Campbell Island, New Zealand (Roberts, 1973). ZI-ZVI: zoea I to VI, M: megalopa and CI: crab I.

that was however mainly attributed to caridean shrimps (Christiansen and Anger, 1990; Wehrtmann and Albornoz, 2003; Anger, 2006). Unfavourable environmental conditions such as low food availability, or unsuitable temperature and salinity, either in nature or in the laboratory, can modify the developmental sequence of decapod larvae (Thatje and Bacardit, 2000; Wehrtmann and Albornoz, 2003; and references therein). Although less common, such variability has also been reported from brachyuran and anomuran species (Christiansen and Anger, 1990). Particularly in galatheids, it has been described for Galathea dispersa (Lebour, 1930), Pleuroncodes planipes (Boyd and Johnson, 1963), Pleuroncodes monodon (Faggeti and Campodonico, 1971), Galathea rostrata (Gore, 1979), and Galathea intermedia (Christiansen and Anger, 1990). The pattern of morphological plasticity in larvae, and larval developmental pathways was discussed as an advantage for species living in unstable environments (Wehrtmann and Albornoz, 2003; and references therein).

The average size of the zoeae I obtained in the laboratory was similar to that of field-collected larvae obtained from the Islas Malvinas/Falkland Islands and Campbell Island, New Zealand (Rayner, 1935; Roberts, 1973; respectively) (Fig. 3). However, in the laboratory, subsequent larval stages were always smaller than those from the plankton. These results are consistent with similar findings in other crustaceans (Wehrtmann and Albornoz, 2003; and references therein). Differences in the nutritional condition of larvae from the plankton and those cultured in the laboratory can explain the size differences found between both environments (Wehrtmann and Albornoz, 2003). Overall, the diet in the laboratory consisting of freshly hatched Artemia spp. 
nauplii might have not been optimal for larval development (high mortality and low growth), since Artemia nauplii may have a lower nutritional value than natural zooplankton (for discussion, see also Thatje et al., 2004; Gimenez and Anger, 2005; and references therein). Theoretically, the additional zoeal instar six found in our cultures might be attributed to a nutritional deficiency as well. However, since there was no variability observed in the larval pathway (for discussion see Wehrtmann and Albornoz, 2003; Thatje et al., 2004) we postulate that the additional instar was previously overlooked or simply not obtained.

Females used in this study were probably late larvae hatchers since there is no evidence that in the Beagle Channel this species spawns twice a year. Larvae used in this study hatched on the 7th, 8th and 13th of December 2004, from ovigerous females caught in the Beagle Channel on the 4th of December 2004, the end of the hatching period that begins in August (c.f. Lovrich, 1999). This extended hatching period can be explained by the fact that female energy intake constrains ovarian development (Romero, 2003): females that feed on high quality food can develop their oocytes in time to spawn during May (Tapella et al., 2002a) and hatch larvae in August. Low quality food can delay oocyte development and subsequently delay spawning and hatching times (c.f. Romero, 2003). Therefore, although an individual female hatches the whole egg batch in a single night, the variability in female energy intake could result in an extended population hatching period occurring from August to December.

Early life history strategies in subantarctic decapods are highly diverse, ranging from fully planktotrophic larval developments, as for example, in the present squat lobsters (Thatje et al., 2003), to tendencies of abbreviated planktotrophic larval developments in shrimps (Thatje et al., 2003) and even complete lecithotrophy is known for some anomuran lithodid crabs (Lovrich et al., 2003). Species with extended planktotrophic and thus actively feeding larvae, at high latitudes need to synchronize larval release with phytoplankton production in spring, in order to allow their larvae to complete their development under the presence of food during short summers (Lovrich and Thatje, 2006). The Beagle Channel represents one of the southernmost sites in the distribution of M. subrugosa, which typically occurs in temperate waters of the Atlantic continental shelf. However, the subantarctic M. subrugosa does not show any tendency to abbreviate its larval cycle in subantarctic latitudes.

In the Beagle Channel, where two or three peaks of plankton chlorophyll are recorded during each spring/ summer (Hernando, pers. comm.), hatching seems to be in phase with primary production. Intraspecific variability in hatching times in $M$. subrugosa might enable the species to cope with potential variability in food availability in the southern spring. Even if a female extrudes her eggs in a single night, the variability in hatching times among females would enable the population to cope with the unpredictability of larval food supply typical of high latitudes.

\section{Acknowledgements}

The authors would like to thank Marcelo Gutiérrez and Marcelo Pérez for their assistance in the field; Nahuel Eriksson, Analia Pérez, Emilce Gallo, and Dr. Daniel Roccatagliata for laboratory assistance; and two anonymous reviewers for critically commenting on the manuscript. This project was funded by the Argentine Agencia Nacional de Promoción Científica y Tecnológica (PICT 01-10042). PPB has a doctoral research scholarship of CONICET. [SS]

\section{References}

Anger, K., 2006. Contributions of larval biology to crustacean research: a review. Invert. Repr. Devel. 49, 175-205.

Boyd, C.M., Johnson, M.W., 1963. Variations in the larval stages of a decapod crustacean, Pleuroncodes planipes Stimpson (Galatheidae). Biol. Bull. 124, 141-152.

Chilton, C., 1909. Crustacea of the subantarctic islands of New Zealand. The subantarctic islands of New Zealand, 2, p. 612.

Christiansen, M.E., Anger, K., 1990. Complete larval development of Galathea intermedia Lilljeborg reared in laboratory culture (Anomura: Galatheidae). J. Crustac. Biol. 10, 87-111.

Faggeti, E., Campodonico, I., 1971. Larval development of the red crab Pleuroncodes monodon (Decapoda: Anomura: Galatheidae) under laboratory conditions. Mar. Biol. 8, 70-81.

Gimenez, L., Anger, K., 2005. Effects of temporary food limitation on survival and development of brachyuran crab larvae. J. Plankton Res. 27, 485-494.

Gore, R.H., 1979. Larval development of Galathea rostrata under laboratory conditions, with a discussion on the larval development of the Galatheidae (Crustacea Anomura). Fish. Bull. 76, 781-806.

Gutt, J., Helsen, E., Arntz, W.E., Buschmann, A., 1999. Biodiversity and community structure of the mega-epibenthos in the Magellan region (South America). Sci. Mar. 63, 155-170.

Jillett, J., Zeldis, J., 1985. Aerial observations of surface patchiness of a planktonic crustacean. Bull. Mar. Sci. 37, 609-619.

Lebour, M.V., 1930. The larvae of the Plymouth Galatheidae. I. Munida banffica, Galathea strigosa and Galathea dispersa. J. Mar. Biol. Assoc. U.K. 17, 175-187.

Lovrich, G.A., 1999. Seasonality of larvae of Brachyura and Anomura (Crustacea Decapoda) in the Beagle Channel, Argentina. Sci. Mar. 63 (Supl. 1), 347-354.

Lovrich, G.A., Thatje, S., 2006. Reproductive and larval biology of the sub-Antarctic hermit crab Pagurus comptus reared in the laboratory. J. Mar. Biol. Assoc. U.K. 86, 743-749.

Lovrich, G.A., Thatje, S., Calcagno, J.A., Anger, K., Kaffenberger, A., 2003. Changes in biomass and chemical composition during 
lecithotrophic larval development of the Southern king crab, Lithodes santolla (Molina). J. Exp. Mar. Biol. Ecol. 288, 65-79.

Matthews, L.H., 1932. Lobster-krill. Anomuran Crustacea that are the food of whales. Discov. Rep. V, 467-484.

Pérez-Barros, P., Tapella, F., Romero, M.C., Calcagno, J.A., Lovrich, G.A., 2004. Benthic decapod crustaceans associated with captures of Munida spp. (Decapoda: Anomura) in the Beagle Channel, Argentina. Sci. Mar. 68, 237-246.

Rayner, G.W., 1935. The Falkland species of the crustacean genus Munida. Discov. Rep. X, 209-245.

Roberts, P.E., 1973. Larvae of Munida subrugosa (White), 1847, from Perseverance Harbour, Campbell Island. J. Roy. Soc. N.Z. 3, 393-408.

Romero, M.C., 2003. Hábitos alimentarios y bioenergética de la langostilla Munida subrugosa (Decapoda: Anomura) del Canal Beagle, Argentina. Doctoral thesis, Universidad Nacional de Córdoba, Argentina.

Tapella, F., Lovrich, G.A., Romero, M.C., Thatje, S., 2002a. Reproductive biology of the crab Munida subrugosa (Decapoda: Anomura: Galatheidae) in the Beagle Channel, Argentina. J. Mar. Biol. Assoc. U.K. 82, 589-595.

Tapella, F., Romero, M.C., Lovrich, G.A., Chizzini, A., 2002b. Life history of the galatheid crab Munida subrugosa in sub Antarctic waters of the Beagle Channel, Argentina. In: Paul, A.J., Dawe, E.G., Elner, R., Jamieson, G.S., Kruse, G.H., Otto, R.S., SainteMarie, B., Shirley, T.C., Woodby, D. (Eds.), Crabs in Cold Water Regions: Biology, Management, and Economics. University of Alaska Sea Grant College Program AK-SG-02-01. Fairbanks, AK, USA, pp. 115-134.
Thatje, S., Bacardit, R., 2000. Morphological variability in larval stages of Nauticaris magellanica (A. Milne Edwards, 1891) (Decapoda: Caridea: Hippolytidae) from South American waters. Bull. Mar. Sci. 66, 375-398.

Thatje, S., Schnack-Schiel, S., Arntz, W.E., 2003. Developmental trade-offs in Subantarctic meroplankton communities and the enigma of low decapod diversity in high southern latitudes. Mar. Ecol. Prog. Ser. 260, 195-207.

Thatje, S., Lovrich, G.A., Torres, G., Hagen, W., Anger, K., 2004. Changes in biomass, lipid, fatty acid and elemental composition during abbreviated larval development of the subantarctic shrimp Campylonotus vagans. J. Exp. Mar. Biol. Ecol. 301, 159-174.

Thorson, G., 1936. The larval development, growth and metabolism of Arctic marine bottom invertebrates compared with those of other seas. Medd. Gronl. 100, 1-155.

Thorson, G., 1950. Reproductive and larval ecology of marine bottom invertebrates. Biol. Rev. 25, 1-45.

Villarino, M.F., Simonazzi, M.A., Renzi, M.A., Cañete, G.R., 2002. Estimación de la captura de merluza (Merluccius hubsii) y de la fauna acompañante obtenida como bycatch en la pesquería del langostino patagónico (Pleoticus muelleri) durante el año 2000. INIDEP Inf. Téc. 62, 1-14.

Wehrtmann, I.S., Albornoz, L., 2003. Larvae of Nauticaris magellanica (Decapoda: Caridea: Hippolytidae) reared in the laboratory differ morphologically from those in nature. J. Mar. Biol. Assoc. U. K. 83, 949-957.

Williams, B.G., 1973. The effect of the environment on the morphology of Munida gregaria (Fabricius) (Decapoda, Anomura). Crustaceana 24, 197-210. 